\title{
PENGEMBANGAN E-MODUL PADA MATA PELAJARAN PEMROGRAMAN WEB DINAMIS KELAS XI DENGAN MODEL PROBLEM BASED LEARNING DI SMK NEGERI 2 TABANAN
}

\author{
I M Dedi Pebriyawan 1), I Gede Mahendra Darmawiguna2), I Gede Partha Sindu3) \\ ${ }^{1}$ Fakultas Teknik dan Kejuruan, Universitas Pendidikan Ganesha \\ email: dedipebriyawan@gmail.com \\ ${ }^{2}$ Fakultas Teknik dan Kejuruan, Universitas Pendidikan Ganesha \\ mahendra.darmawiguna@undiksha.ac.id \\ ${ }^{3}$ Fakultas Teknik dan Kejuruan, Universitas Pendidikan Ganesha \\ partha.sindhu@undiksha.ac.id
}

\begin{abstract}
Abstrak
Penelitian ini bertujuan (1) Untuk mengimplementasikan pengembangan emodul pada mata pelajaran pemrograman web dinamis kelas XI dengan model Problem Based Learning di SMK Negeri 2 Tabanan. (2) Untuk mengetahui respon siswa dan guru terhadap pengembangan e-modul pada mata pelajaran pemrograman web dinamis kelas XI dengan model Problem Based Learning di SMK Negeri 2 Tabanan.

Metode penelitian yang digunakan dalam penelitian ini adalah research and development $(R \& D)$, dengan model pengembangan ADDIE. Subjek penelitian ini yaitu siswa kelas XI Rekayasa Perangkat Lunak dan guru mata pelajaran pemrograman web dinamis di SMK Negeri 2 Tabanan tahun ajaran 2016/2017. Untuk mengetahui respon siswa dan guru terhadap e-modul diperoleh dengan menggunakan metode angket.

Hasil penelitian menunjukkan bahwa: 1) Hasil implementasi e-modul yang telah dikembangkan pada mata pelajaran pemrograman web dinamis untuk siswa kelas XI Rekayasa Perangkat Lunak dengan menggunakan model pembelajaran Problem Based Learning di SMK Negeri 2 Tabanan dinyatakan berhasil diterapkan berdasarkan beberapa uji yang dilakukan. 2) Hasil analisis data respon siswa menunjukkan bahwa persentase siswa yang memberikan respon sangat baik sebesar $47,37 \%$ persentase siswa yang memberikan respon baik sebesar $52,63 \%$ dan tidak ada siswa yang memberikan respon cukup, kurang, maupun sangat kurang dan mendapatkan presentase tingkat pencapaian e-modul sebesar $91,65 \%$, dilihat dari kesesuaian tampilan, kemudahan penggunaan e-modul, motivasi terhadap siswa dan isi konten. Sedangkan hasil analisis data respon guru mendapatkan hasil sangat baik.
\end{abstract}

Kata kunci: E-Modul, Pemrograman Web Dinamis, Model Problem Based Learning, Blended Learning

\begin{abstract}
The aim of this research are (1) To implementing the development of emodule for Dynamic Web Progamming subject of 11th grade students with Problem Based Learning Model in SMK Negeri 2 Tabanan. (2) To know students and teachers responds towards the development of E-module on Dynamic Web Progamming subject of 11th grade students with Problem Based Learning Model in SMK Negeri 2 Tabanan.

The research method used in this research is Research and Development $(R \& D)$, with ADDIE development model. The subject of this research is 11th students of Software Engineering program along with their teacher of Dynamic Web
\end{abstract}


Programming subject in SMK Negeri 2 Tabanan of the 2016/2017 school year. Questionnaire method is used in order to know the responds of students and teachers.

The result of this research are: (1) Implementation result of e-module which was developed for Dynamic Web Progamming learning subject of 11th grade Software Engineering with Problem Based Learning Model in SMK Negeri 2 Tabanan is applied successfully based on several test. (2) The result of data analysis of students respond shows that the students' percentage that gives "sangat baik" response is $47,37 \%$, the percentage of "baik" is $52,63 \%$, and none of the students that give "cukup, "kurang", or "sangat kurang" response and get a percentage of the level of achievement of the e-module were $91,65 \%$, based on interface, user friendly, students motivation and contents of e-module. Meanwhile, the result of data analysis of teachers' percentage are "sangat baik".

Keywords: E-Module, Dynamic Web Progamming, Problem Based Learning, Blended Learning

\section{PENDAHULUAN}

Pendidikan merupakan suatu aspek yang penting bagi kehidupan manusia. Dengan mendapatkan pendidikan manusia dapat meningkatkan taraf hidupnya. Pendidikan ini sangat terkait dengan proses belajar dan pembelajaran. Konsep belajar berakar pada peserta didik dan konsep pembelajaran berakar pada pendidik. Belajar merupakan proses mental yang terjadi dalam diri seseorang sehingga menyebabkan munculnya perubahan prilaku dan penambahan pengetahuan (Sanjaya, 2008).

Indonesia merupakan negara yang memperhatikan tentang pendidikan masyarakatnya. Sebagai negara berkembang, Indonesia dituntut untuk memiliki sumber daya manusia (SDM) yang baik. Pemerintah Indonesia menyadari pentingnya peran pendidikan bagi kemajuan negara membuat beberapa terobosan dalam bidang pendidikan. Program SMK Bisa adalah suatu program baru dari pemerintah, dimana pemerintah mengajak siswa untuk melanjutkan ke jenjang SMK, karena di SMK banyak sekali terdapat Program Keahlian yang memfokuskan siswanya pada salah satu jurusan dengan target lulusan yang diharapkan memiliki skill dasar dan siap diterjunkan ke masyarakat sesuai dengan Undang-Undang Republik Indonesia No. 2 Tahun 1989 tentang Sistem Pendidikan
Nasional Pasal 11 bahwa Pendidikan Kejuruan merupakan pendidikan yang memepersiapkan peserta didik untuk dapat bekerja dalam bidang tertentu.

SMK Negeri 2 Tabanan merupakan salah satu SMK di Bali, yang merupakan tempat yang bertanggung jawab untuk mengembangkan potensi siswa-siswi di Bali, khususnya daerah Tabanan. Sekolah yang beralamat di Jalan Wisnu Marga, Kecamatan Marga, Kabupaten Tabanan ini menyediakan beberapa program keahlian, yaitu Multimedia dan Rekayasa Perangkat Lunak (RPL). Pemrograman web dinamis adalah salah satu mata pelajaran dari paket keahlian Rekayasa Perangkat Lunak. SMK Negeri 2 Tabanan telah menerapkan kurikulum 2013.

Berdasarkan observasi yang dilakukan peneliti di SMK Negeri 2 Tabanan pada tanggal 28 Desember 2015, peneliti melihat pembelajaran di kelas masih dilakukan dengan konvensional, yaitu dengan metode ceramah yang dibantu dengan penggunaan LCD atau proyektor. Dampak dari hal ini adalah kondisi kelas yang tidak kondusif untuk proses belajar mengajar. Siswa banyak terlihat jenuh dengan pembelajaran, ditambah dengan kurang maksimalnya penggunaan buku panduan bagi siswa. Buku panduan merupakan salah satu komponen penting dalam proses belajar mengajar. 
Untuk mengatasi permasalahan tersebut maka dirasa perlu penggunaan media pembelajaran. Penggunaan media pembelajaran harus dipertimbangkan dengan baik oleh guru demi memperoleh hasil pembelajaran yang baik.

Observasi kedua yang dilakukan pada tanggal 6 Januari 2016 untuk mengetahui karakteristik siswa kelas XI RPL SMK N 2 Tabanan dengan metode penyebaran angket, sebagian besar siswa menyatakan senang mencari sumber-sumber belajar mengenai pemrograman web dinamis di internet dan juga mendukung pembuatan emodul dengan beberapa fitur sehingga pembelajaran menjadi lebih menarik. Namun materi yang diperoleh dari internet rancu dan tidak sesuai dengan struktur kurikulum 2013 yang digunakan. Oleh karena itu siswa memerlukan suatu wadah untuk mengakses materi yang sudah tersusun lengkap. Keterbatasan waktu juga menjadi hambatan guru dalam menyampaikan materi pembelajaran di kelas sehingga guru kekurangan waktu dalam mengontrol pembelajaran.

Pemilihan media pembelajaran sebagai sumber belajar mandiri dapat menambah pengalaman belajar serta dapat membantu siswa mempelajari materi lebih awal sebelum diajarkan dipertemuan berikutnya. Melalui penggunaan media pengajaran diharapkan dapat mempertinggi kualitas proses belajar mengajar yang pada akhirnya dapat mempengaruhi kualitas hasil belajar siswa (Sudjana \& Rivai, 2009). Modul merupakan suatu media pembelajaran yang banyak digunakan pada saat ini. Penggunaan modul dianggap sesuai dan cocok diterapkan dalam kurikulum 2013. Mengikuti perkembangan zaman yang ada, modul pembelajaran kini sudah bisa berpindah ke dalam bentuk $e$ modul. Namun e-modul tidak langsung dapat diterapkan dalam kelas, perlu adanya penyesuaian dengan kondisi dan karakteristik siswa, penyesuaian dengan silabus serta dengan kurikulum yang diterapkan dalam sekolah tersebut. Berdasarkan pada permasalahan tersebut, maka penerapan e-modul dimodifikasi dengan penambahan model pembelajaran. Model pembelejaran yang digunakan disini adalah Problem Based Learning yang merupakan salah satu dari 4 model pembelajaran utama yang pelaksanaanya sesuai dengan Kurikulum 2013 (Kemendikbud, Penguatan Pemahaman Kurikulum 2013 Sekolah Menengah Kejuruan, 2015:23). Terdapat perbedaan hasil belajar antara siswa yang diajar dengan metode PBL dengan yang diajar dengan metode demonstrasi ditinjau dari motivasi tinggi dan rendah. Hasil dari penelitian ini menunjukkan bahwa penggunaan metode PBL memberikan hasil belajar yang lebih baik daripada metode demonstrasi, ditinjau dari siswa yang memiliki motivasi tinggi ataupun rendah (Wulandari, 2013).

Berdasarkan uraian di atas, pengembangan modul sangat penting dilaksanakan karena dapat menambah sumber belajar bagi siswa. Pengembangan modul yang berupa elektronik modul dengan modifikasi berupa penambahan model pembelajaran Problem Based Learning, dapat mengatasi masalah kebosanan siswa dalam proses pembelajaran. Terkait hal ini, sangat penting untuk melakukan pengembangan modul khususnya e-modul pada materi pemrograman web dinamis untuk siswa kelas XI Rekayasa Perangkat Lunak di SMK Negeri 2 Tabanan.

\section{METODE}

Penelitian ini merupakan jenis penelitian pengembangan atau Research and Development $(R \& D)$. Penelitian ini bertujuan untuk mengembangkan e-modul pada mata pelajaran pemrograman web dinamis pada jurusan Rekayasa Perangkat Lunak di SMK Negeri 2 Tabanan. Pengembangan Research and Development ( $R$ \& D) adalah metode penelitian yang digunakan untuk menghasilkan produk 
tertentu, dan menguji keefektifan produk tersebut (Sugiyono, 2011). Dalam penelitian pengembangan atau Research and Development $(R \& D)$ perlu diadakan sebuah analisis kebutuhan untuk mengetahui kebutuhan apa yang diperlukan oleh sistem yang akan dibuat, selain itu analisis kebutuhan juga bertujuan agar sistem yang dibuat nantinya dapat berguna dan efektif berfungsi di lapangan. Terdapat banyak model yang dapat digunakan dalam penelitian pengembangan sesuai dengan kebutuhan, bidang dan langkah-langkah yang dilakukan. Model penelitian yang sering digunakan dalam penelitian pengembangan adalah 4D, Dick \& Carrey dan ADDIE.

Model pengembangan yang digunakan dalam penelitian ini yaitu model pengembangan ADDIE. ADDIE merupakan singkatan dari Analysis, Design, Development or production, Implementation or delivery and Evaluation. Model pengembangan ADDIE ini sering digunakan dalam penelitian atau pengembangan media atau bahan ajar seperti modul, LKS, elearning, e-modul dan buku panduan. Adapun teknik pengumpulan data yang digunakan adalah sebagai berikut :

Tabel 1. Teknik Pengumpulan Data

\begin{tabular}{|c|c|c|c|}
\hline No. & Jenis Data & Metode & Sumber Data \\
\hline 1 & $\begin{array}{l}\text { Informasi tentang } \\
\text { sumber belajar }\end{array}$ & Angket & $\begin{array}{l}\text { Guru Mata Pelajaran Pemrograman Web } \\
\text { Dinamis }\end{array}$ \\
\hline 2 & $\begin{array}{l}\text { Karakteristik } \\
\text { pembelajar }\end{array}$ & Angket & Siswa kelas XI RPL SMK Negeri 2 Tabanan \\
\hline 3 & $\begin{array}{l}\text { Kevalidan E- } \\
\text { modul }\end{array}$ & Angket & $\begin{array}{l}\text { Ahli Isi Pembelajaran, Ahli Desain } \\
\text { Pembelajaran. }\end{array}$ \\
\hline 4 & Respon e-modul & Angket & $\begin{array}{l}\text { Siswa kelas XI RPL dan guru mata pelajaran } \\
\text { Sistem Komputer SMK Negeri } 2 \text { Tabanan }\end{array}$ \\
\hline
\end{tabular}

Pada kegiatan observasi guna mendapat informasi sumber belajar dan karakteristik pembelajar, digunakan jenis metode angket terbuka. Melalui metode angket ini peneliti mengetahui masalah yang terjadi ketika pembelajaran berlangsung terkait sumber belajar, materi, media, dan ketertarikan siswa dalam pembelajaran sistem komputer. Uraian singkat tentang teknis analisis data yang digunakan dalam penelitian ini adalah sebagai berikut.

1. Analisis Data Kevalidan E-Modul

Rumus yang digunakan menghitung persentase masing-masing subyek seperti terdapat pada persamaan 1 .

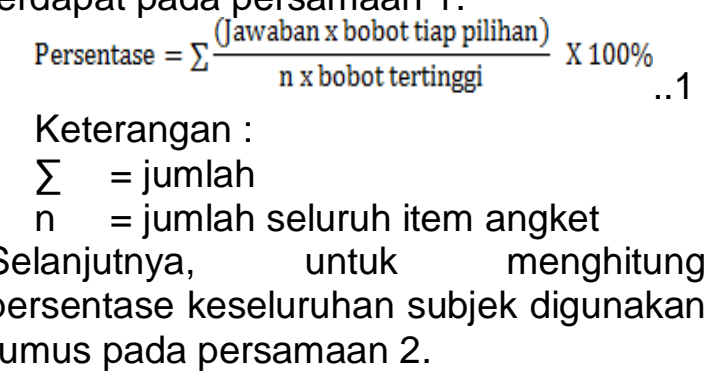

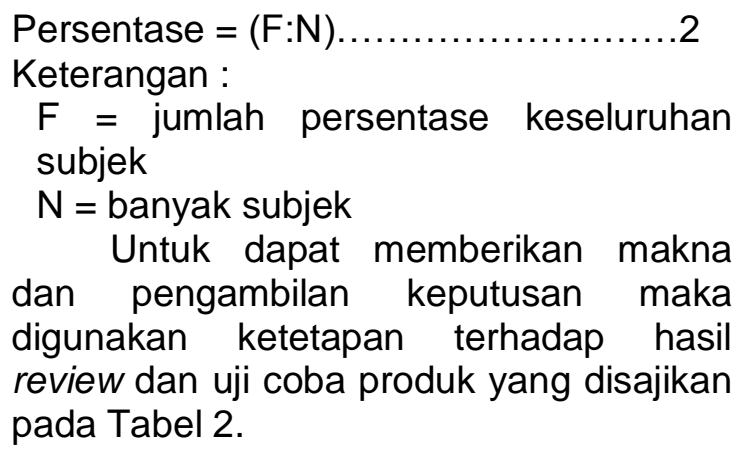
digunakan ketetapan terhadap hasil review dan uji coba produk yang disajikan pada Tabel 2.

Tabel 2. Konversi Tingkat Pencapaian Dengan Skala 5

Tingkat Kualifikasi Keterangan

Pencapaian

(\%)

\begin{tabular}{lll}
\hline $90-100$ & $\begin{array}{l}\text { Sangat } \\
\text { baik }\end{array}$ & $\begin{array}{l}\text { Tidak perlu } \\
\text { direvisi }\end{array}$ \\
\hline $75-89$ & Baik & $\begin{array}{l}\text { Tidak perlu } \\
\text { direvisi }\end{array}$ \\
\hline $65-74$ & Cukup & Direvisi \\
\hline $55-64$ & Kurang & Direvisi \\
\hline
\end{tabular}




\begin{tabular}{lll}
\hline $0-54$ & $\begin{array}{l}\text { Sangat } \\
\text { kurang }\end{array}$ & Direvisi \\
\hline
\end{tabular}

\section{Analisis Data Repson Guru dan Siswa} Untuk melakukan perhitungan analisis data respon maka didasarkan pada ratarata kelas $(\bar{x})$ dari respon siswa, Mi, SDi, seperti rumus pada persamaan 3 .

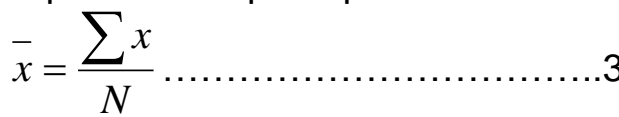

Keterangan:

$\bar{x}=$ Rata - rata kelas untuk skor respon siswa

$\sum x=$ Jumlah skor respon siswa

$\mathrm{N}$ = Banyaknya siswa

Sedangkan untuk mencari mean ideal (Mi) dan standar deviasi ideal (SDi) digunakan rumus seperti terdapat pada persamaan 4 dan 5.

$\mathrm{Mi}=\frac{1}{2}($ skor maksimal + skor terendah $) \ldots \ldots .4$
$\mathrm{SDi}=\frac{1}{2}($ skor tertinggi + skor terendah $) \ldots .5$

Rata-rata kelas $(\bar{x})$ dari skor respon kemudian dikategorikan dengan menggunakan pedoman pada Tabel 3 .

Tabel 3. Kriteria Penggolongan Respon Siswa

\begin{tabular}{lll}
\hline No & \multicolumn{1}{c}{ Interval } & \multicolumn{1}{c}{ Kategori } \\
\hline 1 & $\mathrm{Mi}+1,5 \mathrm{SDi} \leq \bar{x}$ & Sangat Positif \\
\hline 2 & $\mathrm{Mi}+0,5 \mathrm{SDi} \leq \bar{x}<$ & Positif \\
& $\mathrm{Mi}+1,5 \mathrm{SDi}$ & \\
\hline 3 & $\mathrm{Mi}-0,5 \mathrm{SDi} \leq \bar{x}<$ & Kurang Positif \\
& $\mathrm{Mi}+0,5 \mathrm{SDi}$ & \\
\hline 4 & $\mathrm{Mi}-1,5 \mathrm{SDi} \leq \bar{x}<$ & Negatif \\
& $\mathrm{Mi}-1,5 \mathrm{SDi}$ & \\
\hline 5 & $\bar{x}<\mathrm{Mi}-1,5 \mathrm{SDi} \quad$ Sangat Negatif \\
\hline
\end{tabular}

\section{HASIL DAN PEMBAHASAN}

Hasil penelitian yang telah dilakukan adalah sebuah e-modul yang valid pada mata pelajaran pemrograman web dinamis kelas XI RPL di SMK Negeri 2 Tabanan. Sebuah modul yang valid agar dapat digunakan sebagai sumber belajar oleh siswa maka dilakukan pengujian oleh para ahli maupun siswa. Pengembangan modul ini dilakukan oleh para ahli yaitu ahli isi, ahli desain pembelajaran, dan ahli media. Pengujian terhadap siswa dilakukan melalui uji coba perorangan, uji coba kelompok kecil, dan uji coba lapangan. Pemaparan untuk mengetahui hasil dari pengujian akan dijelaskan sebagai berikut.

Pengembangan e-modul sistem komputer menggunakan model pembelajaran problem based learning, dengan tujuan untuk membuat siswa lebih aktif dalam proses pembelajaran. Berdasarkan model pengembangan yang digunakan yaitu ADDIE, maka pada tahap pertama dilakukan analysis (analisis) yang terdiri dari: a) Analisis Tujuan dan Karakteristik Isi Bidang Studi, b) Menetapkan Indikator dan Isi Pembelajaran, c) Menetapkan Strategi Pengorganisasian Isi Pembelajaran, d) Menetapkan Strategi Penyampaian Isi Pembelajaran, e) Menetapkan Strategi Pengelolaan Pembelajaran. Selanjutnya melakukan analisis ketersediaan sumber belajar, dan analisis karakteristik pembelajar. Tahap kedua adalah design (perancangan) yang terdiri dari perancangan draft modul dan perancangan e-modul.

Tahap ketiga adalah development (pengembangan) yang terdiri dari kegiatan pengembangan modul, pengembangan emodul dan integrasi fitur moodle pada emodul. Pada kegiatan pengembangan modul dilakukan kegiatan pengumpulan bahan/materi pelajaran, pengetikan bahan ajar, dan penyusunan materi sesuai kompetensi yang diharapkan. Selanjutnya tahap pengembangan e-modul dilakukan kegiatan yaitu mengembangkan e-modul dengan menggunakan aplikasi Moodle, melakukan pengembangan rancangan antarmuka (interface) pada aplikasi moodle, mengatur tampilan kegiatan pembelajaran. Sedangkan kegiatan pengembangan integrasi fitur moodle pada e-modul meliputi penerapan hasil modul ke moodle hingga menjadi produk akhir berupa e-modul. Pengembangan fitur moodle disesuaikan dengan kerangka 
modul yang digunakan dan dilakukan implementasi tahap problem based learning pada e-modul, yang terdiri dari beberapa langkah yaitu.

1) Memukan masalah

Halaman menemukan masalah pada setiap kegiatan pembelajaran merupakan halaman yang berisikan tentang permasalahan yang diangkat dari konteks kehidupan sehari-hari. Berikut hasil pengembangan tahap menemukan masalah.

\begin{tabular}{l} 
MENEMUKAN MASALAH \\
(10 menit) \\
Pada tahap ini, anda diharapkan untuk menemukan permasalahan dari sebuah \\
soal cerita yang akan diberikan. Berikut adalah permasalahan yang akan \\
diberikan: \\
Masalah 1 \\
\hline
\end{tabular}

Gambar 1 Halaman Menemukan Masalah

2) Mendefinisikan masalah

Pada halaman mendefinsikan masalah, siswa mendefinisikan masalah menggunakan kalimatnya sendiri. Hasil tahap ini dapat dilihat pada Gambar 2

MENDEFINISIKAN MASALAH
(10 menit)
Setelah anda membaca soal cerita di atas, dan menemukan permasalahan. Anda
diminta untuk mendefinisikan permasalahan yang anda temukan. Permasalahan
yang anda temukan mungkin berbeda dengan yang teman anda temukan.
Silahkan definisikan dengan bahasa anda sendiri, melalui fitur obrolan.
Chat Room 1
Not available unless: The activity Masalah 1 is marked complete (hidden
otherwise)

Gambar 2 Halaman Mendefinisikan Masalah

3) Mengumpulkan fakta-fakta

Halaman mengumpulkan fakta-fakta merupakan halaman yang berisi tentang materi yang akan dipelajari oleh siswa Hasil pengembangan halaman mengumpulkan fakta-fakta dapat dilihat pada Gambar 3

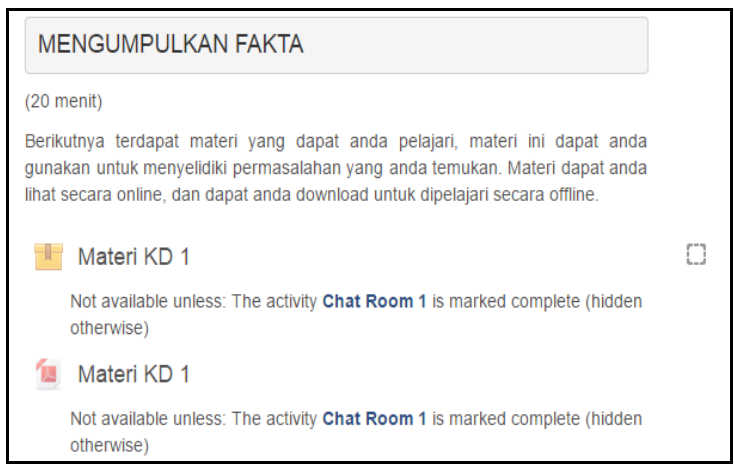

Gambar 3 Halaman Pembelajaran Mandiri

4) Menyusun dugaan sementara

Halaman menyusun dugaan sementara pada setiap kegiatan belajar merupakan halaman yang berisi tahapan diskusi oleh siswa saat sudah menemukan informasi/solusi dari masalah yang diberikan. Siswa berdiskusi dengan kelompoknya masing-masing untuk saling bertukar pendapat mengenai permaslaahan yang diberikan. Hasil pengembangan halaman tahapan pembelajaran mandiri dapat dilihat pada Gambar 4

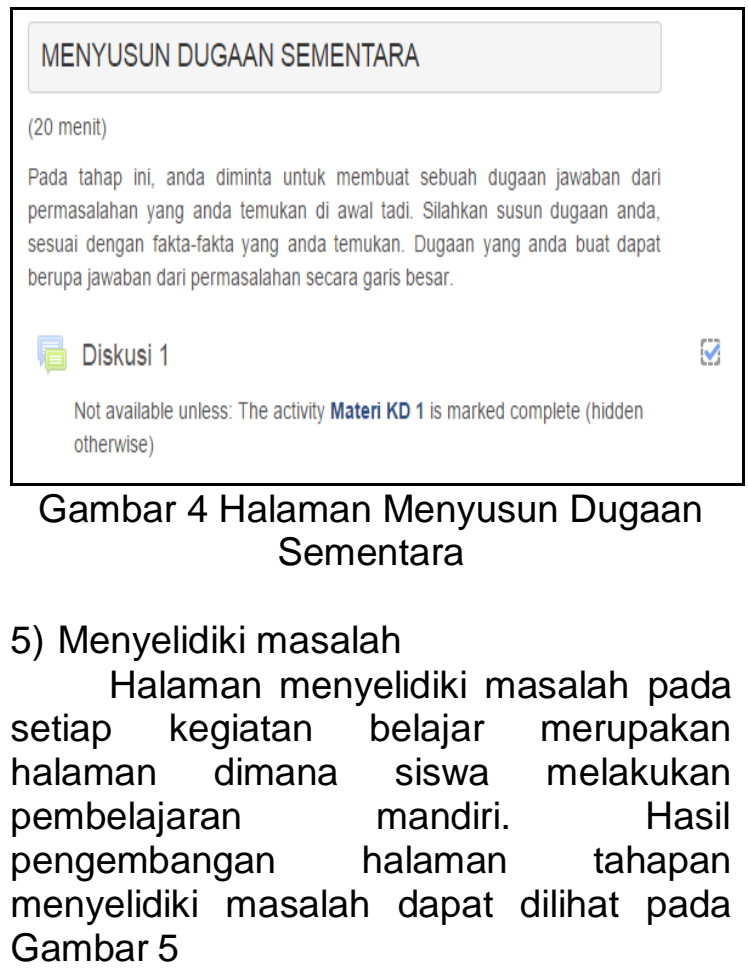




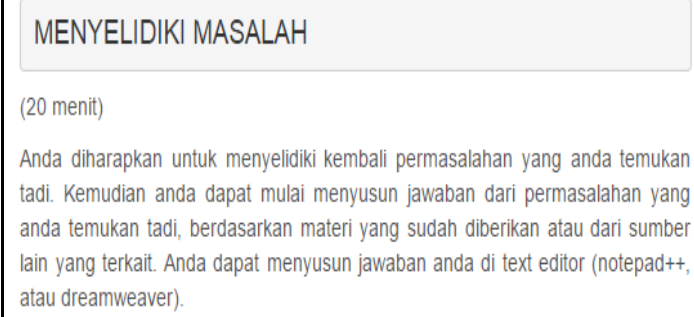

Gambar 5 Hasil Pengembangan Halaman Menyelidiki Masalah

6) Menyempurnakan permasalahan Halaman menyempurnakan masalah pada setiap kegiatan pembelajaran dimana siswa kembali berdiskusi setelah membuat jawaban dari permasalahan yang diberikan. Hasil pengembangan halaman ini dapat dilihat pada Gambar 6

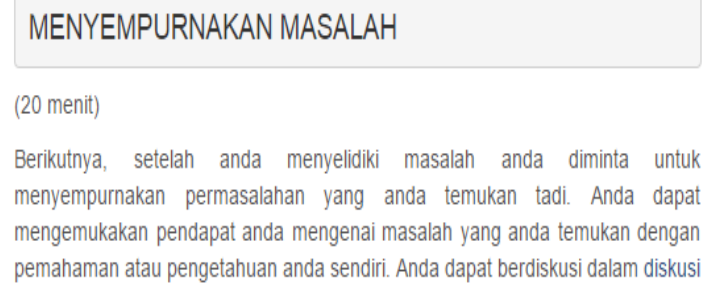

Gambar 6 Halaman Menyempurnakan Masalah

7) Menyimpulkan alternatif masalah Pada halaman menyimpulkan alternatif pemecahan masalah, siswa diarahkan untuk menyusun jawabanjawaban dari permasalahan yang diberikan, siswa juga dapat berdiskusi terakhir kali dengan kelompoknya. Hasil pengembangan halaman ini masalah dapat dilihat pada Gambar 7

MENYIMPULKAN ALTERNATIF PEMECAHAN MASALAH
(20 menit)
Silahkan anda menyusun jawaban dari permasalahan-permasalahan yang anda
temukan. Anda dapat berdiskusi terlebih dahulu dalam diskusi 1. Setelah itu anda
dapat menyusun jawaban anda dalam Microsoft Word.

Gambar 7 Menyimpulkan Alernatif Pemecahan Masalah

8) Menguji solusi masalah
Halaman menguji solusi permasalahan pada kegiatan belajar merupakan halaman dimana siswa mengumpulkan jawaban dari permasalahan yang diberikan. Hasil pengembangan halaman ini dapat dilihat pada Gambar 8

\begin{tabular}{l}
\hline MENGUJI SOLUSI PERMASALAHAN \\
(30 menit) \\
Silankan anda upload laporan anda dengan diberikan judul dengan nama anda, \\
conton : I Made Dedi Pebriyawan.docx \\
Upload Tugas 1 \\
Not available unless: The activity Diskusi 1 is marked complete (hidden \\
otherwise) \\
'un Rubrik Penilaian \\
Gambar 8 Pengembangan Menguji Solusi \\
Permasalahan
\end{tabular}

9) Tahap evaluasi

Halaman evaluasi tes formatif pada kegiatan belajar merupakan halaman yang berisi soal formatif. Pada tahapan ini siswa mengerjakan soal dalam jangka waktu yang telah ditentukan. Hasil pengembangan halaman tahapan ini dapat dilihat pada Gambar 9

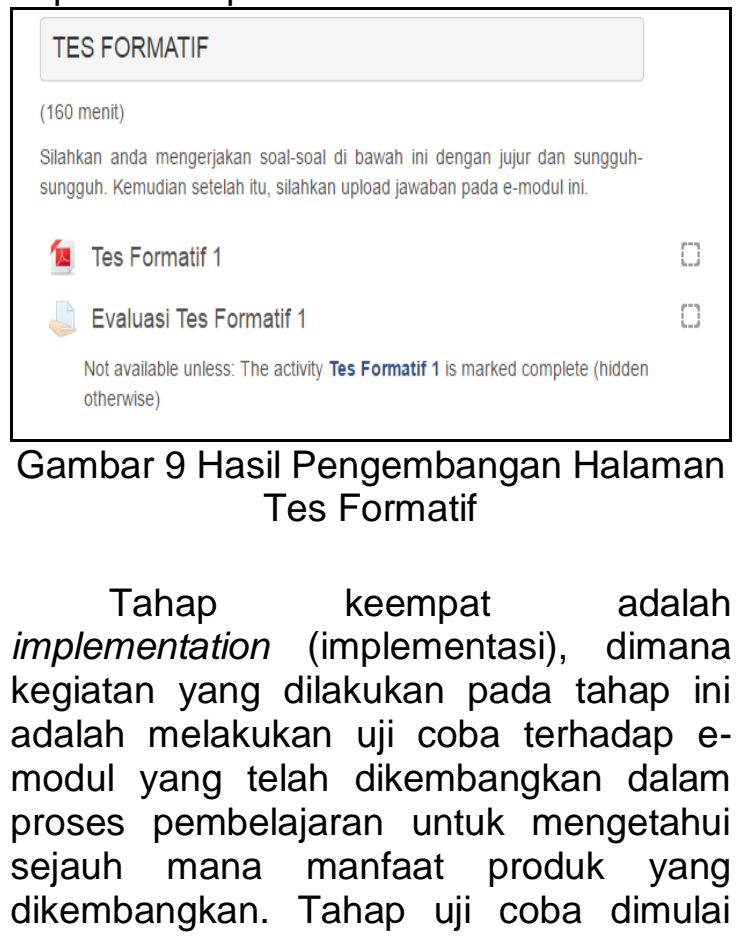


dari uji kevalidan e-modul, kemudian uji coba perorangan, uji kelompok kecil dan uji lapangan.

Setelah e-modul selesaikan dikembangkan selanjutnya dilakukan review ahli untuk dapat meningkatkan kualitas pembelajaran pada e-modul. Pengujian yang dilakukan oleh ahli terdiri dari ahli isi mata pelajaran, ahli desain pembelajaran, dan ahli media pembelajaran.

Hasil penilaian ahli isi berdasarkan angket sudah dinyatakan sesuai, hal tersebut mengindikasi materi yang ada di dalam e-modul layak untuk digunakan dalam pembelajaran pemrograman web dinamis. Beberapa masukan dari ahli isi antara lain perbaikan tampilan dari $e$ modul, kemudian pemberian keterangan terhadap gambar yang dicantumkan dan penambahan soal-soal latihan.

Hasil penilaian dari ahli media adalah pengaturan layout tampilan agar lebih disesuaikan supaya mengurangi space kosong, kemudian penggunaan font agar lebih diperhatikan supaya terlihat rapi dan sistematis.
Hasil dari ahli desain berupa saran mengenai desain pembelajaran, antara lain tinjau kembali langkah-langkah dari problem based learning yang digunakan, beberapa kompetensi dasar yang kurang sesuai dengan problem based learning. Saran dari ahli desain adalah agar permasalahan yang berada pada tahap pendefinisian masalah lebih ditinjau kembali. Kemudian perbaikan terhadap rumusan tujuan pembelajaran agar menggunakan kata kerja operasional.

Setelah dilakukan uji ahli, selanjutnya uji coba perorangan dilakukan dengan menggunakan 3 orang siswa XI RPL. Berdasarkan hasil uji perorangan didapatkan hasil bahwa 1 orang siswa memberikan tanggapan sangat baik $(33,33 \%)$ dan 2 orang siswa memberikan tanggapan baik $(66,67 \%)$ dan tidak ada siswa yang memberikan tanggapan cukup, kurang maupun sangat kurang. Hasil rekapitulasi penilaian pada uji coba perorangan dapat dilihat pada Tabel 4 . Gambar 10 menunjukkan grafik hasil rekapitulasi uji perorangan.

Tabel 4. Rekapitulasi Penilaian Pada Uji Coba Perorangan

\begin{tabular}{lcc}
$\begin{array}{c}\text { Konversi tingkat } \\
\text { pencapaian }\end{array}$ & Persentase (\%) & $\begin{array}{c}\text { Jumlah Responden } \\
\text { (orang) }\end{array}$ \\
\hline k & $33,33 \%$ & 1 \\
kup & $66,67 \%$ & 2 \\
rang & $0 \%$ & 0 \\
\hline nat Kurang & $0 \%$ & 0 \\
\hline
\end{tabular}

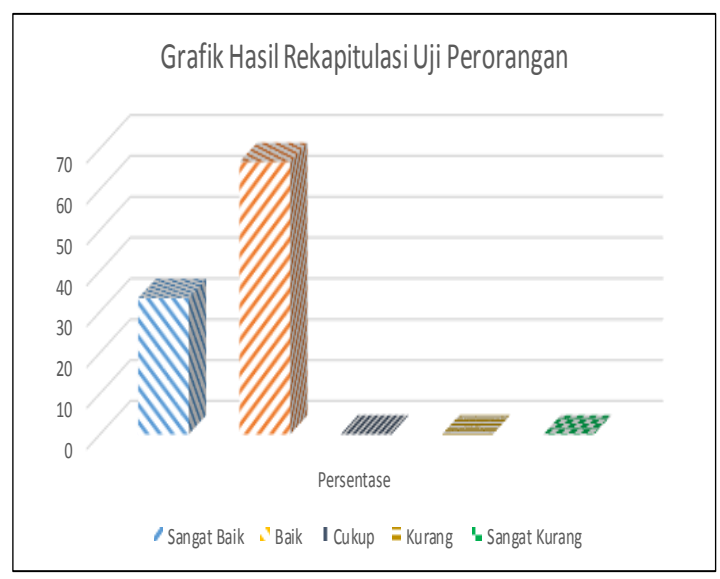

\section{Gambar 10 Grafik Hasil Rekapitulasi Uji Perorangan}

Setelah dilakukan uji coba perorangan, selanjutnya dilakukan uji coba kelompok kecil dengan menggunakan 12 orang siswa XI RPL. Berdasarkan hasil uji kelompok kecil didapatkan hasil bahwa 8 orang siswa memberikan tanggapan sangat baik $(66,67 \%)$ dan 4 orang siswa memberikan

http://ejournal.undiksha.ac.id/index.php/JPTK/issue/view/600 
tanggapan baik $(33,33 \%)$ dan tidak ada siswa yang memberikan tanggapan cukup, kurang maupun sangat kurang. Hasil rekapitulasi penilaian pada uji coba perorangan dapat dilihat pada Tabel 5 . Gambar 11 menunjukkan grafik hasil rekapitulasi uji coba kelompok kecil.

Tabel 5. Rekapitulasi Penilaian Pada Uji Coba Kelompok Kecil

\begin{tabular}{lcc}
\hline $\begin{array}{c}\text { Konversi tingkat } \\
\text { pencapaian }\end{array}$ & Persentase (\%) & $\begin{array}{c}\text { Jumlah Responden } \\
\text { (orang) }\end{array}$ \\
\hline Sangat Baik & $33,33 \%$ & 4 \\
\hline Baik & $66,67 \%$ & 8 \\
\hline Cukup & $0 \%$ & 0 \\
\hline Kurang & $0 \%$ & 0 \\
\hline Sangat Kurang & $0 \%$ & 0
\end{tabular}

Tabel 6. Rekapitulasi Penilaian Pada Uji Coba Lapangan

\begin{tabular}{lcc}
$\begin{array}{c}\text { Konversi tingkat } \\
\text { pencapaian }\end{array}$ & Persentase (\%) & $\begin{array}{c}\text { Jumlah Responden } \\
\text { (orang) }\end{array}$ \\
\hline Sangat Baik & $50 \%$ & 9 \\
\hline Baik & $50 \%$ & 9 \\
\hline Cukup & $0 \%$ & 0 \\
\hline Kurang & $0 \%$ & 0 \\
\hline Sangat Kurang & $0 \%$ & 0 \\
\hline
\end{tabular}

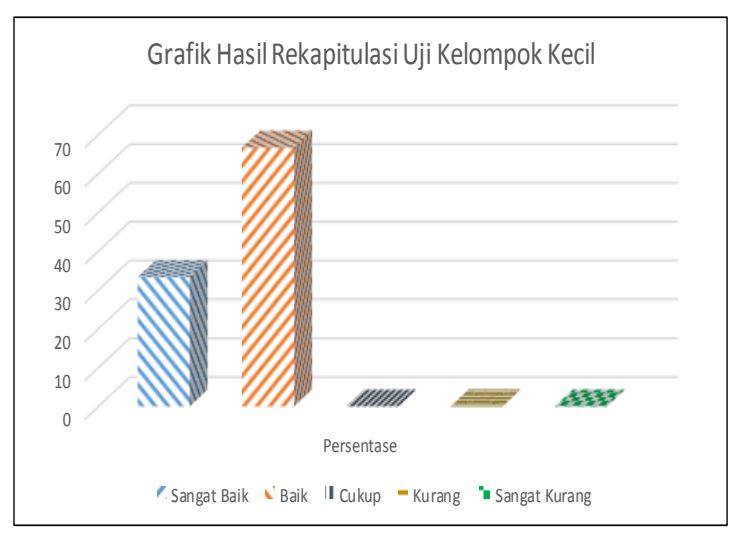

Gambar 11. Hasil Uji Kelompok Kecil

Setelah dilakukan uji coba kelompok kecil, selanjutnya dilakukan uji coba lapangan yang melibatkan 18 orang siswa XI RPL. Berdasarkan hasil uji lapangan didapatkan hasil bahwa 9 orang siswa memberikan tanggapan sangat baik $(50 \%), 9$ orang orang siswa memberikan

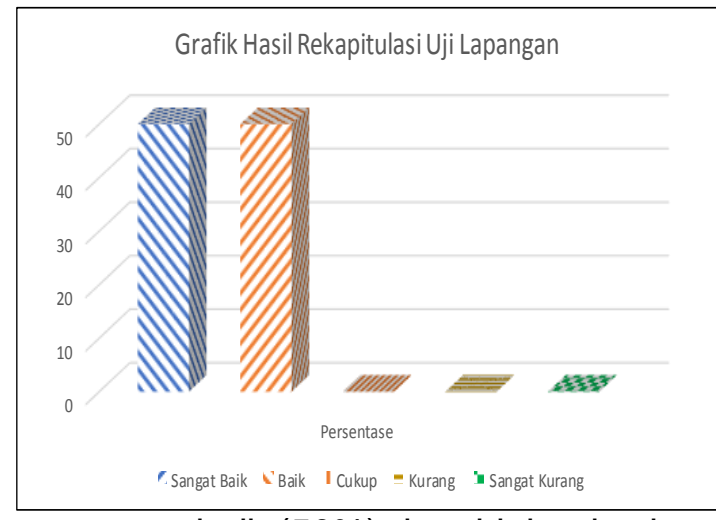

tanggapan baik (50\%) dan tidak ada siswa yang memberikan tanggapan cukup, kurang maupun sangat kurang. Hasil rekaptulasi penilaian pada uji coba lapngan dapat dilihat pada Tabel 6. Gambar 12 menunjukkan grafik hasil rekapitulasi uji coba lapangan.

Setelah melakukan uji perorangan, kelompok kecil, dan lapangan dilakukannya pengambilan respon siswa dan guru. Dimana hasil dari respon siswa 
yaitu sebanyak 9 siswa memberikan respon sangat baik, dan 10 siswa memberikan respon baik.

\section{Gambar 12. Hasil Uji Lapangan}

\section{Berdasarkan rekapitulasi penilaian dari masing-masing responden} memperlihatkan penilaian yang diberikan oleh siswa adalah sangat baik $47,37 \%$, baik $52,63 \%$, cukup $0 \%$, kurang $0 \%$, dan sangat kurang $0 \%$. Hal ini mengindikasi bahwa pengembangan e-modul mata pelajaran pemrograman web dinamis menunjukan keberhasilan yang dibuktikan dengan terbantunya siswa dalam hal pemerolehan sumber belajar.

Selanjutnya dilakukan uji coba perorangan, uji coba kelompok kecil, dan uji coba lapangan. Selanjutnya dilakukan uji respon siswa, berikut adalah hasil uji respon guru. Berdasarkan rekapitulasi penilaian dari masing-masing responden memperlihatkan penilaian yang diberikan oleh guru adalah sangat baik $100 \%$, baik $0 \%$, cukup $0 \%$, kurang $0 \%$, dan sangat kurang $0 \%$. Hal ini mengindikasi bahwa pengembangan e-modul mata pelajaran pemrograman web dinamis menunjukan keberhasilan yang dibuktikan dengan terbantunya siswa dalam hal pemerolehan sumber belajar.

Hasil penelitian ini sesuai dengan penelitian sebelumnya yang dilakukan oleh (Adiputra, 2014) mengenai pengembangan e-modul. Hasil penelitian tersebut mengatakan persentase respon siswa menunjukkan sebesar 66,66\% memberikan respon sangat positif dan $33,33 \%$ memberikan respon positif, dan tidak ada siswa yang memberikan respon kurang positif, negatif maupun sangat negatif. Pengembangan e-modul pada Materi "Melakukan Instalasi Sistem Operasi Jaringan Berbasis GUI dan Text" dapat dikategorikan sangat positif.

Berdasarkan hasil uji yang dilakukan, dapat disimpulkan pengembangan e-modul mata pelajaran pemrograman web dinamis yang telah dibuat menunjukan adanya keberhasilan, dan hal ini terbukti dengan pernyataan siswa yaitu siswa senang menggunakan e-modul dalam pelajaran pemrograman web dinamis dikarenakan e-modul berisikan materi yang jelas (respon siswa) sehingga sudah tersedianya sumber belajar. Terdapat juga pernyataan bahwa dengan adanya e-modul, siswa menjadi lebih tertarik belajar pemrograman web dinamis. Dengan demikian peneliti berhasil mengembangkan e-modul mata pelajaran pemrograman web dinamis dengan model pembelajaran problem based learning yang valid.

Adapun kendala dan solusi serta kelebihan dari pengembangan e-modul ini adalah kendala pertama, beberapa siswa masih belum terbiasa menggunakan $e$ modul. Solusi dari permasalahan ini adalah dengan melatih siswa menggunakan e-modul lebih banyak.

Kendala kedua adalah beberapa siswa masih terlihat banyak bermain ketika menggunakan e-modul, siswa bermain dengan menggunakan fitur chat dan lebih sering menggunakan fitur chat untuk berkomunikasi. Solusi dari permasalahan ini adalah ikut sertanya peran guru dalam proses pembelajaran untuk mengontrol siswa.

Kelebihan dari pengembangan emodul pemrograman web dinamis kelas $\mathrm{XI}$ ini adalah e-modul disesuaikan dengan karakteristik siswa yang memiliki kognitif berbeda, sehingga pengembangan $e$ modul ini dikembangkan dengan menggunakan model pembelajaran problem based learning. Dengan menggunakan model yang sesuai, pembelajaran menjadi terstruktur dan terarah. Pengunaan PBL pada e-modul ini menjadikan e-modul sesuai untuk di terapkan pada kelas dengan kognitif siswa yang berbeda. Pernyataan ini juga sesuai dengan teori yang dinyatakan oleh Sastrawati, yang menyatakan penggunaan model pembelajaran ini didasarkan kepada dapat meningkatkan kemampuan kognitif siswa yang rendah (Sastrawati, 2011). Pernyataan ini juga diperkuat dengan teori yang dikemukakan 
oleh Sastrawati, yang menyatakan bahwa adanya peningkatan terhadap keterampilan berpikir tingkat tinggi pada siswa yang memiliki strategi metakognisi (kemampuan untuk mengontrol ranah atau aspek kognitif) rendah. Penggunaan problem based learning juga menjadi salah satu keunggulan dari e-modul ini (Sastrawati, 2011).

Kelebihan yang kedua yaitu emodul pemrograman web dinamis kelas XI berisi fitur-fitur yang menarik minat siswa untuk belajar pemrograman web dinamis, fitur-fiturnya meliputi CAI dimana siswa menjadi lebih sistematis dan terstruktur dalam proses pembelajaran. Siswa menjadi bisa belajar secara mendiri tahap demi tahap, hal ini sesuai dengan teori yang dikemukakan oleh Susana, yang menyatakan bahwa modul adalah salah satu bentuk bahan ajar, yang dapat digunakan oleh siswa untuk menyelesaikan satu satuan pembelajaran, selanjutnya siswa dapat melangkah maju dan mempelajari satuan pembelajaran berikutnya (Susana, 2015).

\section{SIMPULAN DAN SARAN}

Berdasarkan hasil penelitian dan pembahasan pada penelitian pengembangan e-modul pada mata pelajaran sistem komputer dengan model pembelajaran problem based learning, maka penulis dapat menarik kesimpulan sebagai berikut. (1) Implementasi pengembangan e-modul pemrograman web dinamis dilakukan dengan cara melakukan uji produk pengembangan oleh dosen ahli dan uji coba di sekolah serta pengambilan respon siswa dan guru. Tahap uji yang dilakukan oleh dosen ahli yaitu uji ahli isi pembelajaran, uji ahli desain pembelajaran, dan uji ahli isi media. Setelah dilakukan uji ahli, e-modul diimplementasikan di sekolah dengan melakukan 3 tahap uji yaitu uji perorangan dengan mengambil sampel 3 orang, kemudian tahap uji kelompok kecil mengambil sampel 12, dan tahap uji lapangan mengambil sampel 18 orang pada kelas XI RPL. Setelah dilakukannya semua uji, diambilnya respon siswa dan guru untuk mengetahui respon mereka mengenai penggunaan e-modul pada mata pelajaran pemrograman web dinamis kelas XI, (2) Berdasarkan respon siswa pada e-modul mata pelajaran pemrograman web dinamis kelas XI dengan model problem based learning di SMK Negeri 2 Tabanan, didapatkan ratarata respon siswa sebesar $91,65 \%$ dalam hal kesesuaian tampilan, kemudahan penggunaan e-modul, motivasi terhadap siswa dan isi konten. Jika dikonversikan ke dalam tabel konversi tingkat pencapaian termasuk pada kategori baik. Sedangkan untuk respon guru terhadap emodul didapatkan rata-rata respon sebesar 93,33\% dalam hal kemudahan penggunaan e-modul, antusias siswa, dan pengajaran menggunakan e-modul. Jika dikonversikan ke dalam tabel konversi tingkat pencapaian termasuk pada kategori sangat baik.

Berdasarkan pengamatan penulis, terdapat beberapa hal yang dapat dijadikan bahan pertimbangan untuk ditindak lanjuti. (1) Produk e-modul pemrograman web dinamis dengan model problem based learning di SMK Negeri 2 Tabanan yang dikembangkan belum sampai pada tahap pengukuran hasil belajar akhir siswa dengan e-modul. Oleh karena itu, terbuka bagi para peneliti lain untuk mengkaji lebih jauh pengukuran hasil belajar akhir siswa menggunakan emodul ini. (2) Aplikasi moodle harus dibuat dalam bentuk aplikasi instalasi sehingga pada saat penginstalan moodle pada tempat yang berbeda tidak membutuhkan waktu yang lama.

\section{DAFTAR PUSTAKA}

Adiputra, I. N. (2014). Pengembangan EModul pada Materi "Melakukan Instalasi Sistem Operasi Jaringan Berbasis GUI dan Text" untuk Slswa Kelas X Teknik Komputer dan Jaringan SMK Negeri 3 Singaraja. Kumpulan Artikel Mahasiswa Pendidikan Teknik Informatika (KARMAPATI), 19-25. 
Kemendikbud. (2015). Penguatan

Pemahaman Kurikulum 2013

Sekolah Menengah Kejuruan.

Handout Pendamping

Implementasi Kurikulum 2013

SMK Tahun 2015, 23.

Peraturan Pemerintah Republik Indonesia No. 47 Tahun 2008 Tentang Wajib Belajar. (t.thn.). Diambil kembali dari kemenag.go.id/file/dokumen/PP47 08.pdf

Sanjaya, W. (2008). Strategi Pembelajaran. Jakarta: Kencana Predana Media.

Sastrawati, E. (2011). Problem Based Learning, Strategi Metakognisi, Dan Keterampilan Berpikir Tingkat Tinggi Siswa. Tekno Pedagogi, 114.

Sudjana, N., \& Rivai, A. (2009). Media Pengajaran. Bandung: Sinar Baru Algensindo.

Sugiyono. (2011). Metode Penelitian Kuantitatif, Kualitatif Dan $R \& D$. Bandung: Alfabeta.

Susana, Y. (2015). Pengembangan Modul IPA Terpadu Berbasis Berpikir Kritis Dengan Tema Ventilator Pada Siswa SMP/MTs Kelas VIII. Jurnal Inkuiri, 109-115.

Tegeh, I. M., \& Kirna, I. M. (2010). Metode Penelitian Pengembangan Pendidikan. Singaraja: Undiksha.

Wulandari, B. (2013). Pengaruh ProblemBased Learning Terhadap Hasil Belajar Ditinjau Dari Motivasi Belajar PLC di SMK. Jurnal Pendidikan Vokasi, 178-191. 